\title{
ANALISIS PENDAPATAN GAPOKTAN MEKAR TANI DALAM PENJUALAN BERAS DI DESA SEBERANG TALUK KECAMATAN KUANTAN TENGAH KABUPATEN KUANTAN SINGINGI
}

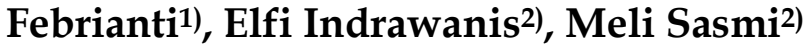 \\ 1) Mahasiswa Program Studi Agribisnis Fakultas Pertanian Universitas Islam \\ Kuantan Singingi Teluk Kuantan Riau Jl. Gatot Subroto KM 7 Jake 29562 \\ ${ }^{2) D o s e n ~ P r o g r a m ~ S t u d i ~ A g r i b i s n i s ~ F a k u l t a s ~ P e r t a n i a n ~ U N I K S ~ T e l u k ~ K u a n t a n ~}$ \\ Riau \\ e-mail : melisasmi2011@gmail.com
}

\begin{abstract}
ABSTRAK
Penelitian ini bertujuan mengetahui sistem penjualan beras, besarnya pendapatan, kelayakan usaha penjualan beras, dan nilai tambah hasil penjualan beras. Penelitian menggunakan metode penelitian survei dimana semua pengurus Gapoktan Mekar Tani dijadikan sebagai responden. Data yang dianalisis dalam penelitian ini terdiri dari sistem penjualan beras, pendapatan, analisis kelayakan usaha penjualan beras (dilihat dari nilai BEP) dan nilai tambah. Hasil penelitian menunjukkan keuntungan rata-rata penjualan beras dengan sistem tradisional sebesar Rp. 29.600.000 per tahun (rata-rata Rp. 2.466.667 per bulan). Keuntungan penjualan beras dengan sistem kemasan (packing) sebesar Rp. 51.415 .160 per tahun (rata-rata Rp. 4.284.597 per bulan), dengan rata-rata produksi perbulan sebesar 850 $\mathrm{kg}$. Rasio penjualan beras dengan sistem tradisional sebesar 1,30, sedangkan penjualan beras dengan sistem kemasan (packing) 1,50. Hal ini menunjukkan usaha penjualan beras dengan sistem tradisional maupun sistem kemasan layak atau efisien. BEP produksi penjualan beras dengan sistem tradisional sebesar $652,17 \mathrm{~kg}$ dan BEP penerimaan penjualan beras dengan sistem tradisional sebesar Rp. 9.622 per $\mathrm{kg}$. BEP produksi penjualan beras dengan sistem kemasan sebesar 563,86 kg dan BEP penerimaan penjualan beras dengan sistem kemasan sebesar Rp. 9.982 per kg. Nilai tambah hasil penjualan beras dengan sistem tradisonal sebesar Rp. 2.743 per kg, sedangkan sistem kemasan sebesar Rp. 5.027 per kg. Penjualan beras dengan sistem kemasan memiliki nilai tambah yang lebih tinggi dibanding dengan sistem tradisional. Rasio nilai tambah penjualan beras dengan sistem tradisional sebesar 21,94 sedangkan rasio nilai tambah dengan sistem kemasan sebesar 33,51. Dengan demikian rasio nilai tambah ini masuk kategori $\leq 50$ persen, yaitu dikategorikan rendah.
\end{abstract}

Kata Kunci: Pendapatan, Beras, Penjualan 


\section{PENDAHULUAN}

Kebutuhan beras secara nasional terus meningkat seiring dengan bertambahnya jumlah penduduk dan masih tingginya tingkat konsumsi beras, tingginya alih fungsi lahan ke non pertanian yang berdampak pada penurunan produksi padi, kondisi iklim yang tidak menentu dan berdampak negatif yaitu mempengaruhi pertanaman dan produksi padi, kecenderungan berkurangnya tenaga produktif di bidang pertanian, dan berbagai permasalahan lain yang secara umum berdampak pada tingginya kebutuhan dan ketersediaan pangan khsususnya beras. Namun disisi lain, permasalahan ini sebenarnya harus dilihat sebagai peluang atau potensi keuntungan bagi petani.

Di Provinsi Riau produksi padi sawah berdasarkan laporan Badan Pusat Statistik Provinsi Riau tahun 2014 adalah sebesar 385.475 ton padi GKG (Anonimous, ‘a. 2015). Selanjutnya pada tahun 2015 produksi padi sebesar 393.917 ton padi GKG atau meningkat sebesar 8.442 ton (2,19 persen) dibandingkan produksi tahun 2014. Peningkatan produksi padi terjadi karena adanya peningkatan luas panen sebesar 1.509 Ha (1,42 persen) disertai dengan peningkatan produktivitas yang cukup siginifikan, yaitu 0,28 ton per Ha $(0,76$ persen) dibanding tahun 2014. Berdasarkan musim panen tahun 2015, peningkatan luas panen terbesar secara absolut terjadi pada realisasi panen periode Januari-April 2015 yaitu sebesar 7.690 Ha (naik 13,81 persen) dibandingkan dengan luas panen pada periode yang sama tahun sebelumnya (Anonimous, 'b. 2016).

Kondisi yang sama juga terjadi di Kabupaten Kuantan Singingi dimana pada tahun 2014 produksi padi sebesar 52.030,39 ton GKG atau setara dengan $32.883,21$ ton beras. Untuk memenuhi kebutuhan beras bagi 363.870 penduduk dengan tingkat konsumsi sebesar 114,7 kg perkapita pertahun, maka kebutuhan beras mencapai $41.746,81$ ton setiap tahunnya. Dengan demikian Kabupaten Kuantan Singingi masih kekurangan stok beras sebesar 8.863,60 ton setiap tahunnya (Anonimous, 'c. 2015).

Secara umum kekurangan beras selama ini dipenuhi dari pasokan provinsi dan kabupaten tetangga seperti Sumatera Barat, Jambi, Indragiri Hilir, dan beberapa daerah lain yang terdekat. Untuk mengatasi kekurangan produksi dan mengantisipasi tingkat kebutuhan beras, pemerintah Kabupaten Kuantan Singingi telah melakukan berbagai upaya untuk meningkatkan produksi beras yaitu dengan pemberian insentif yang merupakan keberpihakan pemerintah pada petani yang diharapkan mampu memberikan spirit dan motivasi yang pada akhirnya petani bergairah lagi untuk menanam padi.

Sementara itu untuk meningkatkan pendapatan petani perlu diimbangi dengan sistem pemasaran yang menguntungkan petani. Permasalahan yang sering dihadapi petani adalah permasalahan harga beras yang dipasarkan petani 
masih rendah dibandingkan dengan harga beras yang berasal dari luar Kabupaten Kuantan Singingi sehingga menyebabkan pendapatan petani menjadi rendah.

Perkembangan saat ini pemasaran beras sudah mulai dikelola dalam wadah kelompok tani. Bahkan pada beberapa desa telah dibentuk Gabungan Kelompok Tani yang digunakan sebagai wadah dalam mengembangkan dan melaksanakan kegiatan pemasaran.

Di Kabupaten Kuantan Singingi saat ini sudah terbentuk beberapa Gabungan Kelompok Tani yang mengelola usaha penggilingan padi. Salah satu Gapoktan yang sudah mengelola penggilingan padi dan telah memasarkan beras adalah Gapoktan Mekar Tani yang berdomisili di Desa Seberang Taluk Kecamatan Kuantan Tengah.

Penjualan beras yang dikelola oleh Gapoktan Mekar Tani telah mengarah pada peningkatan nilai tambah terhadap usaha penjualan beras yaitu penggunaan kemasan (packing) dalam penjualannya serta dengan menerapkan manajemen sistem pemasaran modern yang bertujuan untuk meningkatkan pendapatan petani. Sistem penjualan yang dilakukan Gapoktan tersebut belum sepenuhnya menggunakan sistem kemasan (packing) karena masih ada yang dijual dalam bentuk kiloan atau literan. Namun sistem penjualan yang diterapkan saat ini belum dilakukan analisis pendapatan dalam penjualan beras oleh Gapoktan baik dengan menggunakan kemasan (packing) maupun secara tradisional. Berdasarkan uraian diatas maka telah dilakukan penelitian dengan judul : "Analisis Pendapatan Gapoktan Mekar Tani dalam Penjualan Beras di Desa Seberang Taluk Kecamatan Kuantan Tengah Kabupaten Kuantan Singingi".

\section{METODOLOGI}

Penelitian ini dilaksanakan di Desa Seberang Taluk, Kecamatan Kuantan Tengah, Kabupaten Kuantan Singingi pada Gapoktan Mekar Tani. Pemilihan Gapoktan dikarenakan Gapokan yang pertama di Kabupaten Kuantan Singingi yang melakukan penjualan beras dengan sistem kemasan (packing). Penelitian ini dilaksanakan pada bulan Juli 2016. Teknik pengumpulan data dilakukan dengan beberapa metode, yaitu wawancara, observasi dan pencatatan.

Penelitian ini termasuk pada metode penelitian survei, dimana data diambil dari beberapa anggota populasi representatif mewakili seluruh anggota populasi. Metode penentuan responden yang digunakan yaitu metode purposive sampling. Responden yang dipilih disini adalah pengurus Gapoktan Mekar Tani yang berjumlah 9 orang yang berdomisili di Desa Seberang Taluk.

Data yang dikumpulkan pada penelitian ini meliputi data primer, yaitu profil responden (umur, pendidikan, sarana dan prasarana, pengalaman usaha dan perkembangan Gapoktan Mekar Tani, serta biaya produksi. Serta data 
sekunder, yaitu data yang diambil dari intansi terkait seperti monografi daerah penelitian, data statistik serta data lain yang berhubungan dengan penelitian ini.

Analisis data yang digunakan dalam penelitian ini terdiri dari sistem penjualan beras, pendapatan, analisis kelayakan usaha penjualan beras (dilihat dari nilai BEP), dan nilai tambah. Analisa sistem penjualan beras dilakukan dengan melihat dan menganalisa sistem yang dilakukan pada Gapoktan Mekar Tani Desa Seberang Taluk.

Analisis pendapatan yaitu dengan menghitung hasil pengurangan antara total penerimaan dengan total biaya yang dikeluarkan, dengan mencatat seluruh penerimaan dan pengeluaran dari penjualan beras sesuai dengan kapasitas Gapoktan Mekar Tani. Penerimaan total adalah merupakan hasil kali dari jumlah penjualan produksi dalam kilogram $(\mathrm{kg})$ dengan harga jual dalam satuan rupiah (Rp). Pengeluaran total adalah semua biaya yang dikeluarkan dalam proses produksi. Pengeluaran total dibagi dalam dua bagian, yaitu biaya variabel dan biaya tetap. Perhitungan pendapatan usaha atas biaya total secara matematis adalah sebagai berikut (Soekartawi, 2006) :

$$
\begin{gathered}
\pi=T R-T C \\
T R=y x P_{y} \\
T C=T F C+T V C
\end{gathered}
$$

Untuk mengetahui efisiensi suatu usaha terhadap penggunaan satu unit input dapat digambarkan juga dengan nilai rasio keuntungan dan biaya yang merupakan perbandingan antara keuntungan yang diterima dari setiap rupiah yang dikeluarkan dalam proses penjualan beras.

Menurut Soekartawi (2006), analisis R/C merupakan perbandingan antara total penerimaan dan total biaya. Secara matematis, analisis $\mathrm{R} / \mathrm{C}$ dapat dirumuskan sebagai berikut :

$$
R / C=\frac{\text { Total Penerimaan }}{\text { Total Biaya }}
$$

Menurut Soekartawi (2006), jika dihasilkan nilai $\mathrm{R} / \mathrm{C}=1$, maka kegiatan usaha dikatakan tidak mengalami keuntungan ataupun kerugian, atau dengan kata lain total penerimaan yang diperoleh sama besarnya dengan total biaya produksi yang dikeluarkan. Jika $\mathrm{R} / \mathrm{C}>1$, maka penerimaan yang diperoleh lebih besar dari total biaya produksi yang dikeluarkan sehingga kegiatan usaha mengalami keuntungan. Jika $\mathrm{R} / \mathrm{C}<1$, maka total penerimaan yang diperoleh lebih kecil dari total biaya produksi yang dikeluarkan, sehingga kegiatan usaha yang dijalankan mengalami kerugian.

Menurut Harahap (2004), dalam analisa laporan keuangan dapat digunakan rumus BEP untuk mengetahui : 1) Hubungan antara penjualan dan laba; 2) Struktur biaya tetap dan biaya variabel; 3) Kemampuan Gapoktan dalam 
menekan biaya dan batas dimana Gapoktan tidak mengalami laba dan rugi; 4) Hubungan cost, volume, harga dan laba. Selain itu BEP juga untuk mengetahui pada tingkat produksi berapa sehingga titik pulang pokok Gapoktan dan pada penerimaan berapa sehingga tercipta titik pulang pokok. Rumus yang digunakan untuk menghitung BEP adalah :

1. BEP dalam Produksi

2. BEP dalam Penerimaan

$$
B E P=\frac{T F C+A V C}{P_{y}}
$$

$$
B E P=\frac{T F C+A V C}{Y}
$$

Untuk melihat besar nilai tambah ditingkat petani, maka digunakan rumus perhitungan nilai tambah dengan metode Hayami (Suryana, 1990) yaitu :

$$
N T=N P-(N B B+N B P)
$$

Dari metode Hayami dilakukan resifikasi model sehingga pada penelitian penjualan beras ini diperoleh perhitungan nilai tambah yaitu :

$$
\begin{aligned}
N T & =T H P-(T C+T H B) \\
& =T H P-T C-T H B
\end{aligned}
$$

Rasio Nilai Tambah didapat dari pembagian antara Nilai Tambah dengan Nilai Output yang dinyatakan dalam persen (\%). Nilai Output merupakan total penerimaan dari hasil penjualan beras menggunakan kemasan (THP).

$$
\text { Rasio Nilai Tambah }(\%)=\frac{\text { Nilai Tambah }}{\text { Nilai Output }(\text { THP })} \times 100
$$

Kriteria ujinya, yaitu :

Jika Rasio Nilai Tambah $>50 \%$, maka nilai tambah tergolong tinggi. Jika Rasio Nilai Tambah $\leq 50 \%$ maka nilai tambah tergolong rendah.

Menurut Dwi Martani (2012) metode yang dipakai untuk mencari penyusutan adalah metode garis lurus dimana metode ini merupakan metode yang paling sederhana mengasumsikan adanya penggunaan yang konstan dari suatu aset selama masa manfaatnya. Untuk menghitung biaya penyusutan digunakan rumus :

$$
\text { Biaya Penyusutan }=\frac{\text { Harga Pembelian }- \text { Nilai Residu }}{\text { Usia Ekonomis }}
$$




\section{HASIL DAN PEMBAHASAN}

\section{Gambaran Umum Daerah Penelitian}

\section{Geografi dan Topografi}

Desa Seberang Taluk merupakan desa yang terdapat di Kecamatan Kuantan Tengah Kabupaten Kuantan Singingi Provinsi Riau yang terletak 3 km dari ibukota Kecamatan Kuantan Tengah, 6,5 km dari ibukota Kabupaten Kuantan Singingi, dan 167 km dari ibukota Provinsi Riau. Luas wilayah Desa Seberang Taluk 5.479.32 Ha. Secara geografis batas wilayah Desa Seberang Taluk di sebelah Timur berbatasan dengan Desa Seberang Taluk Hilir, sebelah Barat berbatasan dengan Desa Pulau Aro, sebelah Selatan berbatasan dengan Kecamatan Gunung Toar dan sebelah Utara berbatasan dengan Sungai Kuantan.

Desa Seberang Taluk merupakan daerah yang cocok untuk tanaman pangan khususnya padi sawah karena terletak di dataran rendah yang mempunyai topografi datar dengan ketinggian 300 meter diatas permukaan laut. Jenis tanah didominasi oleh tanah PMK (Podzolik Merah Kuning). Suhu udara berkisar antara $29-35^{\circ} \mathrm{C}$ dengan curah hujan rata-rata antara 1.000-3.000 $\mathrm{mm} /$ tahun.

\section{Penduduk}

Jumlah penduduk Desa Seberang Taluk sebanyak 1.790 jiwa, terdiri dari 1.027 orang laki-laki dan 763 orang perempuan. Komposisi umur 0-17 tahun 482 orang ( 26,92 persen), umur $18-56$ tahun 1.040 orang $(58,10$ persen) dan umur diatas 56 tahun 268 (14,97 persen).

Berdasarkan tingkat pendidikan, komposisi penduduk Desa Seberang Taluk terdiri dari : pendidikan sarjana 115 orang (6,42 persen), akademi/D1-D3 123 orang (6,87 persen), SMA 650 orang (36,31 persen), SMP 295 orang (16,48 persen), SD 315 orang (17,59 persen), dan yang tidak/belum sekolah 170 orang (9,50 persen).

\section{Sarana dan Prasarana}

Sarana dan prasarana yang dimiliki Desa Seberang Taluk terdiri dari: Kantor Kepala Desa, puskesmas 1 unit, TK 1 unit, SD 1 unit, SMP 1 unit, mesjid 1 unit, musholla 5 unit, sarana perekonomian (toko/kios/kedai) 20 unit dan bengkel 4 unit.

\section{Karakteristik Responden}

Responden dalam penelitian ini adalah pengurus Gapoktan Mekar Tani. Karakteristik yang diamati dalam penelitian ini meliputi umur dan tingkat pendidikan responden, serta pengalaman usaha dan perkembangan Gapoktan Mekar Tani. 


\section{Umur Pengurus}

Berkaitan dengan umur dengan kemampuan dalam bekerja, Hernanto (1993) menyatakan bahwa angkatan kerja berusia produktif adalah mereka yang berada pada usia 15-45 tahun dan kurang produktif pada usia 45-65 tahun yang kemudian menjadi tidak produktif lagi pada usia $>65$ tahun.

Komposisi umur Pengurus Gapoktan Mekar Tani yang berjumlah 9 orang terdiri dari : 1 orang umur 30-44 tahun, 6 orang umur 45-49 tahun, dan 2 orang umur diatas 50 tahun.

Dengan jumlah pengurus yang berumur 45-49 tahun sebanyak 6 orang yang merupakan kelompok umur kurang produktif, akan berpengaruh terhadap kemampuan pengurus untuk berpikir atau untuk mengambil suatu kebijakan.

\section{Pendidikan Pengurus}

Soeharjo dan Patong (1987) menjelaskan bahwa pendidikan pada umumnya akan mempengaruhi cara berpikir petani. Pendidikan yang relatif tinggi dan umur muda menyebabkan petani lebih dinamis. Budiman (1995) menyatakan bahwa hasil kajian Inkes dan Smith menggambarkan bahwa pendidikan merupakan faktor yang paling penting dalam menciptakan manusia yang berkualitas.

Tingkat pendidikan Pengurus Gapoktan Mekar Tani bervariasi yaitu tamatan SD 2 orang, tamatan SMP 4 orang dan tamatan SMA 3 orang. Jika dilihat dari tingkat pendidikan pengurus Gapoktan Mekar Tani yang umumnya hanya sampai tingkat SMP, diikuti oleh tamatan SMA dan SD, akan berpengaruh terhadap perkembangan usaha Gapoktan. Hal ini berkaitan dengan pola pikir dan kemampuan manajerial serta dalam hal pengambilan kebijakan.

\section{Pengalaman Usaha}

Syaifuddin (2008) menyatakan pengalaman yang berulang-ulang dalam situasi tertentu menimbulkan perubahan tingkah laku seseorang dalam situasi tertentu sebagai proses belajar. Pengalaman usaha pengurus Gapoktan Mekar Tani dalam mengelola Gapoktan masih relatif kurang yaitu kurang dari 4 tahun. Kurangnya pengalaman pengurus Gapoktan ini berdampak pada rendahnya aspek inovasi dan inisiatif dalam mengembangkan usaha dan mengelola keanggotaan.

\section{Perkembangan Gapoktan Mekar Tani}

Di Desa Seberang Taluk pada awalnya dibentuk kelompok Tani Sadar pada tahun 2009 dengan 25 orang anggota kelompok dan sampai tahun 2011 jumlah anggota kelompok Tani Sadar telah mencapai 276 orang. Mengingat banyaknya jumlah anggota dan bertambah luasnya lahan sawah, maka pada tanggal 28 Februari 2011 Kelompok Tani Sadar dipecah menjadi 5 kelompok tani. Selanjutnya berdasarkan keputusan hasil rapat atau musyawarah seluruh anggota 
kelompok tani, maka dibentuklah satu Gapoktan yang diberi nama Gapoktan Mekar Tani.

Selanjutnya pada tanggal 20 Juni 2011 Gapoktan Mekar Tani dikukuhkan oleh Camat Kuantan Tengah menjadi kelas kelompok Lanjut.Dengan penerapan beberapa paket teknologi budidaya padi sawah di kelompok tani ini, terjadi peningkatan produktifitas yang signifikan dari rata-rata produksi 3-4 ton per ha menjadi rata-rata 6-7 ton per ha.

Pada perkembangan berikutnya anggota Gapoktan Mekar Tani mulai mengelola usaha tani kearah agribisnis yaitu melakukan kerjasama dengan pihak Swalayan Mandiri yang ada di Kabupaten Kuantan Singingi. Dari aspek jenis usaha, anggota Gapoktan Mekar Tani tidak hanya mengelola komoditi tanaman pangan saja, tetapi juga berusaha dibidang peternakan antara lain kerbau, sapi, kambing, itik dan ayam serta bidang perikanan yaitu kolam ikan dan tambak atau keramba.

Dengan berbagai aktivitasnya, Gapoktan Mekar Tani telah banyak mengukir prestasi yang ditandai dengan penerimaan beberapa penghargaan baik tingkat kabupaten, provinsi dan nasional sehingga desa tetangga dan desa-desa lain di Kabupaten Kuantan Singingi selalu mengadakan studi banding ke Desa Seberang Taluk.

Dalam aspek sarana dan prasarana, Gapoktan Mekar Tani telah memfasilitasi penyediaan sarana dan prasarana pendukung diantaranya : 1) Hand tractor 2 unit dan power tresher 2 unit; 2) Penggilingan Padi Kecil (PPK); 3) Rumah penggilingan padi kecil (swadaya); 4) Gudang saprodi; 5) Pintu air 2 unit; 6) Jalan usaha tani (JUT) 200 m; 7) Perluasan Areal Tanam padi sawah (PAT) $10 \mathrm{Ha}$; 8) Peningkatan Indeks Pertanaman (IP 200).

\section{Analisis Sistem Penjualan}

Sistem penjualan beras yang dilakukan oleh Gapoktan Mekar Tani dikelola dengan 2 (dua) sistem yaitu : 1) Penjualan beras dengan sistem tradisional yaitu penjualan beras tanpa menggunakan kemasan; 2) Penjualan beras dengan sistem kemasan (packing) yaitu penjualan beras yang telah dikemas (packing) dengan kemasan karung ukuran $10 \mathrm{~kg}$ dan telah diberi merek dagang dengan nama Beras Kuansing. Penjualan beras dengan kemasan ini umumnya dilakukan melalui mini market/swalayan.

\section{Analisis Pendapatan dan Penjualan Beras dengan Sistem Tradisional}

\subsection{Analisis Biaya Produksi Penjualan Beras Dengan Sistem Tradisional}

Pembiayaan yang dikeluarkan oleh Pengurus Gapoktan Mekar Tani dalam proses produksi dan penjualan beras merupakan biaya-biaya yang dikeluarkan untuk rata-rata produksi perbulan yang terdiri dari biaya tetap dan biaya variabel. Pada Tabel 1 berikut dijelaskan biaya-biaya yang ditimbulkan dalam proses produksi. 
Tabel 1. Biaya Produksi Penjualan Beras dengan Sistem Tradisional pada Gapoktan Mekar Tani (Rp/kg) Tahun 2015.

\begin{tabular}{lccr}
\hline \multicolumn{1}{c}{ Uraian } & $\begin{array}{c}\text { Biaya Tetap } \\
\text { (TFC) }\end{array}$ & $\begin{array}{c}\text { Biaya Variabel } \\
\text { (VC) }\end{array}$ & $\begin{array}{c}\text { Jumlah } \\
\text { (TC) }\end{array}$ \\
\hline Mesin pengilingan padi & 260.417 & & 260.417 \\
Timbangan & 20.000 & & 20.000 \\
Ember jumbo & 6.667 & & 6.667 \\
Tikar penjemuran (terpal) & 18.750 & & 18.750 \\
Mesin jahit karung & 25.000 & & 25.000 \\
Biaya sewa gudang & 200.000 & & 200.000 \\
Pembelian gabah & & 5.663 .333 & 5.663 .333 \\
Transport pembelian gabah & & 141,583 & 141.583 \\
Upah penjemuran & & 566.333 & 566.333 \\
Upah operator & & 750.000 & 750.000 \\
Biaya BBM & & 260.000 & 260.000 \\
Biaya pelumas & & 140.000 & 140.000 \\
Biaya pemeliharaan mesin & & 100.000 & 100.000 \\
\hline \multicolumn{1}{c}{ Total Biaya } & $\mathbf{5 3 0 . 8 3 3}$ & $\mathbf{7 . 6 2 1 . 2 5 0}$ & $\mathbf{8 . 1 5 2 . 0 8 3}$ \\
\hline
\end{tabular}

Sumber : Data Olahan

Berdasarkan data pada Tabel 1 dapat dilihat jumlah rincian biaya tetap rata-rata perbulan yaitu sebesar Rp. 530.833, sedangkan biaya variabel rata-rata perbulan sebesar Rp. 7.621.250. Total biaya produksi rata-rata perbulan sebesar Rp. 8.152.083. Pada penelitian ini biaya yang terbesar terdapat pada biaya pembelian gabah yaitu Rp. 5.663.333. Untuk biaya tetap jumlahnya lebih kecil dibanding dengan biaya variabel, hal ini disebabkan oleh harga mesin giling padi, timbangan, ember jumbo, mesin jahit karung dan terpal yang dihitung berdasarkan nilai penyusutan dengan memperhitungkan nilai ekonomis atau usia ekonomis.

\section{Analisis Keuntungan Penjualan Beras dengan Sistem Tradisional pada Gapoktan Mekar Tani}

Analisis keuntungan dilakukan terhadap jumlah rata-rata penjualan beras perbulan oleh Gapoktan Mekar Tani pada penjualan beras dengan sistem tradisional. Tabel 2 menggambarkan tingkat keuntungan yang diterima Gapoktan Mekar Tani dengan produksi rata-rata perbulan. 
Tabel 2. Analisis Penjualan Beras dengan Sistem Tradisional pada Gapoktan Mekar Tani Desa Seberang Taluk Tahun 2015

\begin{tabular}{|c|c|c|}
\hline No & Variabel & Jumlah \\
\hline 1 & Jumlah gabah (kg) & 1.416 \\
\hline 2 & Harga beli gabah (Rp/kg) & 4.000 \\
\hline 3 & Total biaya pembelian gabah (Rp/kg) & 5.663 .333 \\
\hline 4 & Harga jual beras (Rp/kg) (Py) & 12.500 \\
\hline 5 & $\operatorname{Margin}(\mathrm{Rp} / \mathrm{kg})$ & 8.500 \\
\hline 6 & Total produksi (Kg) & 850 \\
\hline 7 & Penerimaan (Rp) & 10.618 .750 \\
\hline 8 & Total biaya (Rp) & 8.152 .083 \\
\hline 9 & Keuntungan (Rp) & 2.466 .667 \\
\hline
\end{tabular}

Sumber : Data Olahan

Berdasarkan data pada Tabel 2 dapat dilihat bahwa jumlah pembelian gabah rata-rata perbulan $1.416 \mathrm{~kg}$ dengan harga $\mathrm{Rp} .4 .000$ per $\mathrm{kg}$ dan total biaya pembelian gabah rata-rata perbulan sebesar Rp. 5.663 .333 yang dikonversikan menjadi beras (60 persen) rata-rata perbulan $850 \mathrm{~kg}$ dengan harga jual Rp. 12.500 per kg. Sedangkan penerimaan yang diperoleh Gapoktan Mekar Tani sebesar Rp. 10.618.750. Biaya yang dikeluarkan untuk produksi rata-rata perbulan sebesar Rp. 8.152.083 yang terdiri dari biaya tetap dan biaya variabel. Jadi keuntungan yang diperoleh Gapoktan Mekar Tani dari rata-rata produksi perbulan sebesar Rp. 2.466.667. Dari analisis penjualan beras dengan sistem tradisional yang dilakukan oleh Gapoktan Mekar Tani, usaha penjualan beras tersebut menguntungkan dan usaha tersebut layak diusahakan.

\section{Analisis Return Of Cost Ratio}

Analisis Return Of Cost Ratio merupakan analisis pendapatan yang digunakan untuk mengetahui tingkat pendapatan yang diperoleh oleh Gapoktan Mekar Tani. Berdasarkan nilai TR yaitu Rp. 10.618 .750 dan nilai TC yaitu Rp. 8.152.083, diperoleh nilai $\mathrm{R} / \mathrm{C}$ usaha penjualan beras 1,30 artinya Rp. 1 biaya yang dikeluarkan dalam proses produksi beras oleh Gapoktan Mekar Tani, diperoleh penerimaan sebesar 1,30 rupiah atau diperoleh keuntungan sebesar 30 rupiah. Jika nila $\mathrm{R} / \mathrm{C}>1$, maka total penerimaan yang diperoleh lebih besar dari total biaya produksi yang dikeluarkan sehingga kegiatan usaha yang dilakukan oleh Gapoktan Mekar Tani dalam penjualan beras dengan sistem tradisional mengalami keuntungan, artinya usaha yang dilakukan layak untuk diusahakan.

\section{Analisis Break Event Point (BEP)}

Analisis Break Event Point merupakan analisis yang digunakan untuk mengetahui kemampuan Gapoktan Mekar Tani dalam menekan biaya dan batas dimana usaha tidak mengalami laba dan rugi. Disamping itu analisis Break Event 
Point juga untuk mengetahui pada tingkat produksi berapa sehingga usaha balik modal pokok dan pada penerimaan berapa sehingga tercipta titik balik modal.

Berdasarkan hasil analisa BEP penjualan beras dengan sistem tradisional yaitu nilai TC sebesar Rp. 8.152.083 dan harga jual sebesar Rp. 12.500 per kg, diperoleh nilai BEP produksi yaitu titik balik modal tercapai bila tingkat produksi rata-rata perbulan $652,17 \mathrm{~kg}$. Artinya hasil penjualan beras dengan sistem tradisional yang dilakukan oleh Gapoktan Mekar Tani hanya kembali modal dengan volume produksi rata-rata perbulan 652,17 kg. Kalau volume produksi rata-rata perbulan kurang dari $652,17 \mathrm{~kg}$, maka hasil penjualan beras dengan sistem tradisional dianggap rugi. Agar usaha penjualan beras yang dilakukan Gapoktan Mekar Tani tidak mengalami kerugian, maka perlu diupayakan agar volume gabah yang diolah dapat ditingkatkan.

Selanjutnya dengan volume produksi beras per bulan sebesar $850 \mathrm{~kg}$, diperoleh nilai BEP penerimaan yaitu titik balik modal tercapai bila harga penjualan Rp. 9.622 per kg. Artinya hasil penjualan beras dengan sistem tradisional yang dilakukan oleh Gapoktan Mekar Tani akan balik modal dengan harga penjualan Rp. 9.622 per kg. Jika harga penjualan kurang dari Rp. 9.622 per $\mathrm{kg}$ maka hasil penjualan beras tersebut rugi. Untuk meningkatkan harga jual perlu peningkatan mutu produksi atau perlu nilai tambah dengan menambah kemasan (packing) sehingga nilai jual akan lebih tinggi.

\section{Analisis Pendapatan Penjualan Beras dengan Sistem Kemasan (Packing) Analisis Biaya Produksi Penjualan Beras dengan Sistem Kemasan (Packing)}

Pembiayaan yang dilakukan oleh Pengurus Gapoktan Mekar Tani dalam proses produksi dan penjualan beras merupakan biaya-biaya yang dikeluarkan untuk rata-rata produksi perbulan yang terdiri dari biaya tetap dan biaya variabel. Tabel 3 menggambarkan biaya-biaya yang ditimbulkan dalam proses produksi.

Tabel 3. Analisis Biaya Produksi Penjualan Beras dengan Sistem Kemasan (Packing) pada Gapoktan Mekar Tani Tahun 2015

\begin{tabular}{lrrr}
\hline \multicolumn{1}{c}{ Uraian } & $\begin{array}{c}\text { Biaya Tetap } \\
\text { (TFC) }\end{array}$ & $\begin{array}{c}\text { Biaya Variabel } \\
\text { (VC) }\end{array}$ & Jumlah (TC) \\
\hline Mesin pengilingan padi & 260.417 & & 260.417 \\
Timbangan & 20.000 & & 20.000 \\
Ember jumbo & 6.667 & & 6.667 \\
Tikar penjemuran (terpal) & 18.750 & & 18.750 \\
Mesin jahit karung & 25.000 & & 25.000 \\
Biaya sewa gudang & 200.000 & & 200.000 \\
Pembelian Gabah & & 5.663 .333 & 5.663 .333 \\
Transport pembelian gabah & & 141.583 & 141.583 \\
Upah tenaga penjemuran & & 566.333 & 566.333 \\
Upah operator & & 750.000 & 750.000 \\
\hline
\end{tabular}




\begin{tabular}{lrrr}
\hline \multicolumn{1}{c}{ Uraian } & $\begin{array}{c}\text { Biaya Tetap } \\
\text { (TFC) }\end{array}$ & $\begin{array}{c}\text { Biaya Variabel } \\
\text { (VC) }\end{array}$ & Jumlah (TC) \\
\hline Biaya BBM & & 260.000 & 260.000 \\
Biaya pelumas & & 140.000 & 140.000 \\
Biaya pemeliharaan mesin & & 100.000 & 100.000 \\
Karung kemasan & & 135.920 & 135.920 \\
Transport pemasaran beras & & 84.950 & 84.950 \\
Upah tenaga pengemasan & & 84.950 & 84.950 \\
\hline \multicolumn{1}{c}{ Total Biaya } & $\mathbf{5 3 0 . 8 3 3}$ & $\mathbf{7 . 9 2 7 . 0 7 0}$ & $\mathbf{8 . 4 5 7 . 9 0 3}$ \\
\hline
\end{tabular}

Sumber : Data Olahan

Berdasarkan data pada Tabel 3 dapat dilihat jumlah rincian biaya tetap rata-rata produksi perbulan sebesar Rp. 530.833, sedangkan biaya variabel sebesar Rp. 7.927.070 dan total biaya produksi sebesar Rp. 8.457.903. Pada penelitian ini biaya yang terbesar terdapat pada biaya pembelian gabah sebesar Rp. 5.663.333. Untuk biaya tetap jumlahnya lebih kecil dibanding dengan biaya variabel, ini disebabkan harga mesin giling padi, timbangan, ember jumbo, mesin jahit karung dan terval dihitung berdasarkan nilai penyusutan dengan memperhitungkan nilai ekonomis atau usia ekonomis.

\section{Analisis Keuntungan Penjualan Beras dengan Sistem Kemasan (Packing) pada Gapoktan Mekar Tani}

Analisis keuntungan dilakukan terhadap jumlah rata-rata penjualan beras oleh Gapoktan Mekar Tani dalam memasarkan beras dengan sistem kemasan dengan rata-rata produksi perbulan. Tabel 4 menggambarkan tingkat keuntungan yang diterima Gapoktan Mekar Tani dengan rata-rata produksi perbulan.

Tabel 4. Analisis Penjualan Beras dengan Sistem Kemasan (Packing) pada Gapoktan Mekar Tani Desa Seberang Taluk Tahun 2015

\begin{tabular}{clrr}
\hline No & \multicolumn{1}{c}{ Variabel } & Jumlah \\
\hline 1 & Jumlah gabah $(\mathrm{kg})$ & & 1.416 \\
2 & Harga pembelian gabah $(\mathrm{Rp} / \mathrm{kg})$ & 4.000 \\
3 & \multicolumn{2}{l}{ Total biaya pembelian gabah $(\mathrm{Rp})$} & 5.663 .333 \\
4 & Harga jual beras $(\mathrm{Rp} / \mathrm{kg})$ & $(\mathrm{py})$ & 15.000 \\
5 & Margin $(\mathrm{Rp} / \mathrm{kg})$ & & 11.000 \\
6 & Total produksi $(\mathrm{Kg})$ & $(\mathrm{y})$ & 850 \\
7 & Penerimaan $(\mathrm{Rp})$ & $(\mathrm{TR})$ & 12.742 .500 \\
8 & Total biaya $(\mathrm{Rp})$ & $(\mathrm{TC})$ & 8.457 .903 \\
9 & Keuntungan $(\mathrm{Rp})$ & $($ п $)$ & 4.284 .597 \\
\hline
\end{tabular}

Sumber : Data Olahan

Berdasarkan data pada Tabel 4 dapat dilihat bahwa jumlah pembelian gabah rata-rata perbulan $1.416 \mathrm{~kg}$ dengan harga $\mathrm{Rp} .4 .000$ per $\mathrm{kg}$ dan total biaya 
pembelian gabah rata-rata perbulan sebesar Rp. 5.663 .333 dikonversikan menjadi beras $(60 \%)$ rata-rata perbulan $850 \mathrm{~kg}$ dengan harga jual Rp. 15.000 per kg. Sedangkan penerimaan yang diperoleh Gapoktan Mekar Tani sebesar Rp. 12.742.500. Biaya yang dikeluarkan untuk produksi rata-rata perbulan sebesar Rp. 8.457.903 yang terdiri dari biaya tetap dan biaya variabel. Jadi keuntungan yang diperoleh Gapoktan Mekar Tani dari rata-rata produksi perbulan sebesar Rp. 4.284.597. Dari analisis penjualan beras dengan sistem kemasan (packing) yang dilakukan oleh Gapoktan Mekar Tani, usaha tersebut menguntungkan dan usaha tersebut layak diusahakan. Jika produksi dapat ditingkatkan lagi tentu akan memperoleh keuntungan yang lebih besar. Besarnya keuntungan akan berdampak terhadap peningkatan pendapatan anggota Gapoktan Mekar Tani Desa Seberang Taluk.

\section{Analisis Return Of Cost Ratio}

Analisis Return of Cost Ratio merupakan analisis pendapatan yang digunakan untuk mengetahui tingkat pendapatan yang diperoleh oleh Gapoktan Mekar Tani. Berdasarkan nilai TR sebesar Rp. 12.742 .500 dan nilai TC sebesar Rp. 8.457.903, diperoleh nilai R/C sebesar 1,50 artinya Rp. 1 biaya yang dikeluarkan dalam proses produksi beras oleh Gapoktan Mekar Tani, maka diperoleh penerimaan sebesar Rp. 1,50 atau diperoleh keuntungan sebesar 50 rupiah. Jika nilai $\mathrm{R} / \mathrm{C}>1$, maka total penerimaan yang diperoleh lebih besar dari total biaya produksi yang dikeluarkan sehingga kegiatan usaha yang dilakukan oleh Gapoktan Mekar Tani dalam penjualan beras dengan sistem kemasan (packing) mengalami keuntungan, artinya usaha yang dilakukan layak untuk diusahakan.

\section{Analisis Break Event Point (BEP)}

Analisis Break Event Point merupakan analisis yang digunakan untuk mengetahui kemampuan Gapoktan Mekar Tani dalam menekan biaya dan batas dimana Gapoktan Mekar Tani tidak mengalami laba dan rugi. Disamping itu Break Event Point juga untuk mengetahui pada tingkat produksi berapa sehingga mencapai titik balik modal Gapoktan dan pada penerimaan berapa sehingga tercipta titik balik modal.

Berdasarkan hasil analisa BEP penjualan beras dengan sistem kemasan (packing) yaitu nilai TC sebesar Rp. 8.457.903 dan harga jual sebesar Rp. 15.000 per $\mathrm{kg}$, diperoleh nilai BEP produksi yaitu titik balik modal tercapai bila tingkat produksi rata-rata perbulan 563,86 kg. Artinya hasil penjualan beras dengan sistem kemasan (packing) yang dilakukan oleh Gapoktan Mekar Tani akan balik modal dengan volume produksi 563,86 kg perbulannya. Kalau volume produksi kurang dari 563,86 kg maka hasil penjualan beras dengan sistem kemasan (packing) dianggap rugi. Agar penjualan beras dengan sistem kemasan (packing) tidak mengalami kerugian, maka perlu diupayakan agar volume gabah yang diolah dapat ditingkatkan. 
Selanjutnya dengan volume produksi beras per bulan sebesar $850 \mathrm{~kg}$, diperoleh nilai BEP penerimaan yaitu titik balik modal tercapai bila harga penjualan Rp. 9.622 per kg. Artinya hasil penjualan beras dengan sistem kemasan (packing) yang dilakukan oleh Gapoktan Mekar Tani akan kembali modal dengan harga penjualan Rp. 9.982 per kg. Jika harga penjualan kurang dari Rp. 9.982 per $\mathrm{kg}$ maka hasil penjualan beras tersebut rugi.

\section{Nilai Tambah Penjualan Beras}

Harga output merupakan harga total rata-rata penjualan beras per $\mathrm{kg}$, baik dengan sistem tradisional maupun dengan menggunakan sistem kemasan (packing). Pada penjualan beras dengan sistem tradisional total harga output sebesar Rp. 12.500 per kg, sedangkan total harga output untuk penjualan beras dengan sistem kemasan (packing) sebesar Rp. 15.000 per kg. Nilai sumbangan input merupakan total sumbangan dengan jumlah input yang terdiri dari pembelian gabah rata-rata sebesar Rp. 4.000 per kilogram dan biaya yang digunakan untuk produksi sebesar Rp. 5.757 per kilogram. Maka total input yang digunakan dalam penjualan beras dengan sistem tradisional sebesar Rp. 9.757 per kilogram. Nilai tambah dari penjualan beras dengan sistem tradisional sebesar Rp. 2.743 per kilogram. Lebih rinci dapat dijelaskan pada Tabel 5.

Tabel 5. Analisis Nilai Tambah Penjualan Beras dengan Sistem Tradisional Tahun 2015

\begin{tabular}{|c|c|c|c|c|}
\hline $\begin{array}{c}\text { Biaya } \\
\text { produksi } \\
(\mathrm{Rp} / \mathrm{kg})\end{array}$ & $\begin{array}{c}\text { Harga pembelian } \\
\text { gabah } \\
\text { (Rp/kg) }\end{array}$ & $\begin{array}{c}\text { Total biaya } \\
\text { produksi } \\
(\mathrm{Rp} / \mathrm{kg})\end{array}$ & $\begin{array}{c}\text { Harga jual sistem } \\
\text { tradisional } \\
(\mathrm{Rp} / \mathrm{kg})\end{array}$ & $\begin{array}{c}\text { Nilai } \\
\text { tambah } \\
(\mathrm{Rp} / \mathrm{kg})\end{array}$ \\
\hline 5,757 & 4.000 & 9.757 & 12.500 & 2.743 \\
\hline
\end{tabular}

Sumber : Data Olahan

Setelah dilakukan penjualan beras dengan sistem kemasan (packing) oleh Gapoktan Mekar Tani, terjadi peningkatan nilai tambah yaitu sebesar Rp. 5.027 per kilogram. Secara rinci dapat dijelaskan pada Tabel 6.

Tabel 6. Analisis Nilai Tambah Penjualan Beras dengan Sistem Kemasan (Packing) Tahun 2015

\begin{tabular}{ccccc}
\hline $\begin{array}{c}\text { Biaya } \\
\text { produksi } \\
\mathbf{( R p / k g )}\end{array}$ & $\begin{array}{c}\text { Harga pembelian } \\
\text { gabah } \\
\mathbf{( R p / k g )}\end{array}$ & $\begin{array}{c}\text { Total biaya } \\
\text { produksi } \\
\mathbf{( R p / k g )}\end{array}$ & $\begin{array}{c}\text { Harga jual sistem } \\
\text { kemasan } \\
\mathbf{( R p / k g )}\end{array}$ & $\begin{array}{c}\text { Nilai } \\
\text { tambah } \\
\mathbf{( R p / k g )}\end{array}$ \\
\hline 5,973 & 4.000 & 9.973 & 15.000 & 5.027 \\
\hline
\end{tabular}

Sumber : Data Olahan

Peningkatan nilai tambah ini disebabkan oleh sistem penjualan beras yang berbeda oleh Gapoktan Mekar Tani. Penjualan dengan sistem kemasan (packing) 
ternyata menambah tingkat keuntungan dibandingkan dengan sistem penjualan beras dengan sistem tradisional.

Rasio nilai tambah hasil penjualan beras dari sistem tradisional dengan sistem kemasan (packing), rasio nilai tambah terbesar pada hasil penjualan beras terdapat pada penjualan dengan sistem kemasan (packing) yaitu sebesar 33,51, sedangkan penjualan beras dengan sistem tradisional sebesar 21,94. Hal ini disebabkan karena dengan hanya menambah kemasan (packing) dalam penjualan beras sehingga penetapan harga jual dapat lebih tinggi dibandingkan dengan penjualan beras secara tradisional.

Hasil analisis nilai tambah tersebut $\leq 50$ persen, dengan demikian maka nilai tambah pada penjualan beras masih tergolong rendah. Rendahnya nilai tambah penjualan beras hal ini dipengaruhi oleh beberapa faktor yaitu : 1) Tingginya harga penjualan gabah oleh petani kepada Gapoktan Mekar Tani. 2) Biaya produksi dari pengolahan sampai penjualan masih relatif tinggi disebabkan oleh rendahnya volume produksi. 3) Produksi beras Gapoktan Mekar Tani belum mampu bersaing dengan produk beras dari daerah lain sudah terkenal. 4) Harga beras secara umum sudah dibatasi oleh mekanisme harga pasar yang berlaku.

\section{KESIMPULAN}

1. Sistem penjualan beras yang dilakukan oleh Gapoktan Mekar Tani dilakukan dengan 2 (dua) cara yaitu dengan sistem tradisional dan sistem menggunakan kemasan (packing).

2. Pendapatan/keuntungan rata-rata penjualan beras dengan sistem tradisional adalah sebesar Rp. 29.600 .000 per tahun (Rp. 2.466.667 per bulan). Sedangkan pendapatan atau keuntungan penjualan beras dengan sistem kemasan (packing) adalah sebesar Rp. 51.415 .160 per tahun (Rp. 4.284.597 per bulan) dengan rata-rata produksi perbulan sebesar $850 \mathrm{~kg}$.

3. Untuk kelayakan usaha penjualan beras dengan sistem tradisional diperoleh BEP produksi 652,17 kg dan BEP penerimaan penjualan beras sebesar Rp. 9.622. Untuk penjualan beras dengan sistem kemasan (packing) diperoleh BEP produksi $563.86 \mathrm{~kg}$ dan BEP penerimaan penjualan beras sebesar Rp. 9.982 per kg. Dari hasil analisis BEP, kedua sistem penjualan beras layak untuk diusahakan.

4. Nilai tambah hasil penjualan beras dengan sistem tradisional sebesar Rp. 2.743 per kg, sedangkan dengan sistem kemasan (packing) sebesar Rp. 5.027 per $\mathrm{kg}$. Jadi penjualan beras dengan sistem kemasan memiliki nilai tambah yang lebih tinggi dibanding dengan sistem tradisional. 


\section{DAFTAR PUSTAKA}

Adiwilaga A. 1992. Ilmu Usahatani. Alumni, Bandung.

Aprilia PR. 2011. Analisis Pendapatan Usahatani Padi Sawah. [skripsi]. Kupang : Universitas Nusa Cendana.

Anonimous.'a. 2015. BPS Propinsi Riau Pekanbaru.

Anonimous.'b. 2016. BPS Propinsi Riau Pekanbaru.

Anonimous.'c 2015. Petunjuk Pengembangan, Bimbingan Penyuluhan dan Kelembagaan Kelompok Tani. Kabupaten Kuantan Singingi. Dinas Tanaman Pangan. Teluk Kuantan.

Budiman. 1995. Teori Pembangunan Dunia Ketiga. PT. Gramedia Pustaka Utama. Jakarta.

Harahap. 2004. Analisis Kritis atas Laporan Keuangan. Jakarta Raja Grafindo Persada.

Hernanto. 1993. Ilmu Usaha Tani. Penerbit Swadaya. Jakarta

Soekartawi. 2006. Analisis Usaha Tani. Penerbit Universitas Indonesia. Jakarta.

Soeharjo, Patong. 1973. Sendi-sendi Pokok Usaha Tani. Departemen Ilmu Sosial Ekonomi. Fakultas Pertanian. Institut Pertanian Bogor. Bogor.

Suryana A. 1990. Diversifikasi Pertanian dalam Proses Mempercepat Laju Pembangunan Nasional. Pustaka Sinar Harapan. Jakarta. 